\title{
Contact Sessions in Distance Education: Students' Perspective
}

\author{
Dina Tsagari \\ University of Cyprus \\ dinatsa@ucy.ac.cy
}

\section{Abstract}

The value of including student perspectives in identifying learning experiences (such as ideas and assumptions about what constitutes an ideal learning environment or the roles and needs of learners) occupies an important place in distance education (White, 1997). Learners' perspectives are central in this paper, too, as they constitute the core data of a research study that examined the role of 'contact sessions' as part of a delivery system for adults in a distance learning programme.

More specifically, the paper presents findings of a research study that investigated the ways in which a group of Greek EFL teachers, enrolled in a distance learning programme, experienced the effectiveness of their contact meetings. The method of data collection used was reflective learning journals that students kept at the end of their contact sessions for a whole academic year. The results showed that contact sessions are indeed effective and beneficial of the students in that they help them orientate their study, discover interesting ways for improving their learning and encourage them to share their own experience with their peers. Through contact sessions students' motivation for the course is sustained and their morale is kept high thus supporting them to successfully complete their studies. The paper concludes with pedagogical and research recommendations.

\section{Distance Learning Education}

Distance learning $(D L)$ refers to 'a mode of learning in which the learners are working without direct control of the teacher, outside a conventional classroom environment' (White, 1995:208). What primarily characterizes DL is the absence of a teacher to oversee the students' learning process, choice about the content, place, time to study and monitor students' self-direction.

\section{(cc) BY-NC-ND}


A distance context presents learners with different learning challenges and opportunities compared to those experienced in conventional classrooms. For example, distance learners have more opportunities than their classroom counterparts to choose the content and ways they learn; they have more freedom to determine the kinds of tasks they work on and to ignore activities or sections of their learning materials which they do not consider to be personally useful for their development. However, distance learners are involved in continuous management of their learning environment and are faced with numerous decisions and roles (White, 1997, 2003). DL students face challenges which range from immediate demands of their distance learning context and conditions (e.g. isolated study context, maintaining initial motivation, limited access to real-time interactions, etc) to the availability of teacher mediation and learner awareness of the rate and direction of their learning.

The focus of 'learner autonomy' (Benson, 2001; Holec, 1981; Little, 1991), through strategy development and learner training, is emphasized in the DL literature as a way of facilitating independence and enhancing the repertoire of students' learning skills (Hurd, Beaven, \& Ortega, 2001; Paul, 1990). Anderson and Garrison (1998) argue that distance learner autonomy best develops through a commitment on the part of learners to develop and assume responsibility for their learning processes and collaborative control of learning experiences, e.g. through opportunities for meaningful interaction with other learners and teachers. This is in line with approaches of learning which emphasize the importance of negotiation in supporting learners to shape their own learning (Breen \& Littlejohn, 2000). The challenge for $D L$ is then to develop efficient approaches of interaction, collaboration, participation, social presence, learner networks and support systems (White, 2003).

\section{Learner Support Systems: the Case of Contact Sessions}

In discussions related to the organization and management of learner support systems (Mcasson \& Mcasson, 1997; Tait \& Mills, 2002), that is the assistance and guidance that students are offered in open and distance education, Harichandan (2005), recommends the following four components of Learner Support Services (Figure 1).

The components presented in Figure 1 are conceived as being in balance to each other, that is, they need to be framed together if effective services are to be provided. 


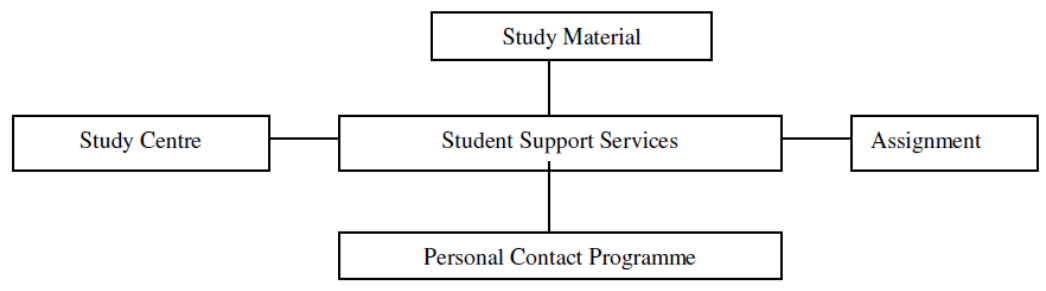

Figure 1. Learner Support Services

Quite a number of $D L$ institutions accommodate student support services known as 'contact sessions' (CS), that is short stints of face-to-face teaching. CS may be offered in the mode of formal teaching, tutorials, seminars or group discussions. In CS, DL students are provided with opportunities for peer interaction, collective guiding, counselling and guidance, clarification of doubts, and problem-solving in using self-learning materials, receiving feedback in specific and difficult concepts/areas, assignments, examinations, etc. (Rowntree, 1992; Simpson, 2002).

CS are accepted as a necessary strategy in many educational systems (Jamtsho, 1999; Rao, Soundaravalli, \& Sarada, 1994). DL institutions that believe in the provision of student support services accommodate face-to-face CS to help students in their study. A number of such institutions make attendance in CS voluntary (Keegan, 2000). In such cases, CS play a supplementary role by providing only revision, tutorial, practical and seminal sessions. No new topics are taught apart from those contained in the self-instructional course materials. These are presented in the form of mini-quizzes, reference lists, samples etc. For instance, the Hellenic Open University (HOU), Greece (www.eap.gr), offers regular CS, on a voluntary basis, for students as part of its delivery system for undergraduate and postgraduate programmes (Papaefthymiou-Lytra, 2001;

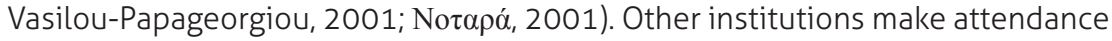
of CS compulsory (see Agboola, 1993; Ushadevi, 1994).

Discussions and research in distance education point to both positive and negative reactions about the usefulness of CS. Holmberg (1982), for instance, states that CS often prove to be very useful and successful in supplementing the study materials, focus on examination topics and activities, offer students opportunities to interact among themselves, and share ideas. Struggling learners, too, see CS as an opportunity to communicate their problems with other learners and tutors alike (Laurillard, 2002). CS are also said to offer necessary input to overcome the social and academic alienation of learners in DL systems (Ushadevi, 1994). CS are also believed to mitigate isolation experienced by DL students (Agboola, 1993), known as 'the isolation syndrome' (Ljosa, 1975). Rogers (1996), in particular, points out that face-to-face CS assist in the release 
of emotions involved in the learning process. Finally, CS are seen to afford personal interaction among participants, contribute towards course completion and reduce the load on other student support services (Rashid, 2009).

However, certain problems are associated with the logistical organisation of CS. For example, Agboola (1993) points out that CS need to be properly organised, e.g. classrooms secured, tutorial staff sought and employed in adequate numbers, meetings scheduled, instructional materials designed and delivered in time, students informed, etc. Also staff selection and recruitment need to be carried out as well as supervision and co-ordination of their activities. In some systems, the overall contribution of CS to DL appears to be of a limited value reporting low student attendance (Fung \& Carr, 2000; Hiola \& Moss, 1990; Morgan \& Morris, 1994), especially when CS play a supplementary role and attendance is optional (Nasseh, 1996).

These observations and findings imply that a bagful of problems attenuate a substantial proportion of the contribution of CS to the effectiveness and efficiency of DL education. These gave rise to the following questions which have shaped the research scope of the present study, e.g.:

- To what extent do CS form a useful component of learner support systems in distance education?

- Are CS really indispensable in distance education?

- In what ways do CS support and contribute to DL?

Against this background, the present study set out to explore DL students' perspectives of distance learning during a whole academic year with an expectation of understanding the effectiveness of CS in a DL programme. More specifically, the study's aim was to:

- explore and illuminate what is happening within the CS of a postgraduate module course offered by a DL institution namely the Hellenic Open University

- explore how communication and teaching practices are managed within the framework of the CS offered in the specific module

- investigate the role of face-to-face CS in support of students' studies.

\section{Context of Present Research}

The Hellenic Open University (HOU) is a State University in Greece that provides DL education via the development and utilization of DL materials and teaching. Since its foundation in 1997, the HOU has catered for the academic needs of a great number of students. For example, in the academic year 2010-2011, the HOU offered 32 undergraduate and postgraduate courses where 1,520 tutors taught 197 thematic modules to 15,430 undergraduate and 17,986 postgraduate students. The figures look really impressive for a tertiary institution 
which offered its first two programmes in 1998. The DL methodology employed by the HOU requires students to:

- study from specially-designed DL materials, study-guides and audiovisual material,

- participate in 4-5 CS for each module taking place in 9 different towns around Greece,

- communicate on an on-going basis with their tutors by telephone, fax, email and letters,

- prepare 4-6 assignments for each module (depending on the structure of the course), and

- take a final examination at the end of each module.

The course under study, the MEd in Teaching English to Speakers of Other Languages (MEd in TESOL), aims at helping graduate students to enhance students' professional development as English language teachers by engaging them in theoretical and practical studies concerning language teaching and learning. The course comprises eight course modules. Students are required to complete four modules before they embark on their final dissertation. Each module is assessed by four assignments. Grading of assignments is done on a scale from 0 to 10 using a specially-designed rating scale that allows also for detailed feedback on the strengths and weaknesses of each assignment.

The module under study, namely the 'Assessment in Language Learning AGG65' mostly selected by third year students, aims at helping EFL teachers whose work involves them in language test construction and development at school level (private or public) to build on their knowledge of language testing and assessment issues. The module introduces students to both theoretical and practical input on current trends in language assessment development, validation and research. For their module assignments, students select and evaluate a range of language assessment methods and develop their own taking into consideration the needs of their teaching situation. So far, approximately 650 students have completed the module. This is quite an encouraging number as the majority of the students are EFL teachers in state schools where training in language test construction and evaluation is scarce. Although $\mathrm{HOU}$ policy does agree with the principle of CS, the usefulness of organising CS in the particular module have not yet been investigated. The present study aimed therefore at evaluating the effectiveness of CS within the context of the Assessment module offered in the Med in TESOL programme.

The cohort of distance learners registered on the module the year the study was conducted (academic year 2009-2010) comprised twenty two teachersin-training (twenty-one female and one male) with years of prior teaching experience. 


\section{Data Collection}

Previous research on the usefulness of CS in the HOU has been conducted by means of questionnaires and interviews exploring mainly the perceptions of students and tutors' attitudes towards them (Papaefthymiou-Lytra, 2001;

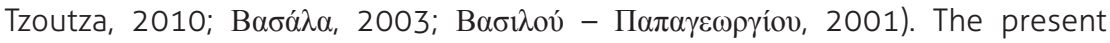
study aimed at focusing on learners' perspective of CS on a longitudinal basis with a view to immediately capturing reactions, feelings, experiences, etc after students had experienced them. Therefore, other data collection procedures were sought for in the relevant literature that could record the immediacy of the students' learning experiences.

The method which suggested itself as the most feasible was the use of 'reflective journals' . Bailey \& Ochsner (1983) stress that journals can provide an emic perspective of students' learning experiences. Bailey (1983:98) sees that journals allow researchers to see the 'dynamic and complex process through the eyes of the learners' while Genesee \& Upshur (1996:120) stress that journals give learners the opportunity to express their views, thoughts and experiences on a wide variety of topics and areas, such as students' learning experiences inside and outside learning environments, attitudes towards themselves, their teachers, their expectations, learning goals, interests, etc. before these are forgotten or lose their immediacy and significance (see also Sturman, 1996). Matsumoto (1987) also emphasises that journal studies can shed light on 'hidden psychological variables such as [...] learning strategies, decision making, self-esteem and sources of enthusiasm' (ibid: 26) which were of interest in the present study.

Inspired mainly by the above literature, the possibility of using learner journals as a data collection instrument for the present study sounded promising. Journals suggested themselves as a way of collecting data discreetly and regularly providing also a description of 'phenomena over time'. This was important in the present study because the period over which data was to be collected needed to be long enough to capture behaviour and events of interest in the study.

However, despite their popularity, journal writing is not without limitations. For example, it is said that if journal writing is unstructured, journal entries tend to be about anything which appears to be significant when reflecting on learning events and outcomes (the 'naturalistic approach', Palmer \& Palmer, 1994). Even though this might result in very interesting and widely varying responses, it is likely that informants will self-select the information they believe to be interesting and might provide less data or produce a preponderance of trivia or comments that will be difficult to analyse especially in the case of large numbers of respondents (Banerjee, 2004). To avoid such problems, the literature (Hettich, 1990; Stevenson \& Jenkins, 1994; Symon, 1998) suggests that researchers give 
their informants guidance (the 'interventionist approach', Palmer \& Palmer, 1994) so as to exert more control over the content of the journals e.g. through a combination of closed and open-ended questions (Banerjee, 2004). In the present study, students were provided with a pro-forma (see Appendix A) with open questions that they were asked to answer at the end of their five CS to avoid the problems discussed above.

\section{Analysis and Interpretation of the Results}

At the end of the data collection period, all journal entries were processed and coded. The responses were initially sorted into answers to the questions included in the journal pro-forma on the basis of their similarities and differences and then placed into conceptual categories based on emergent themes and categories. The analytical process, based on principles of grounded theory (Charmaz, 2006; Glaser, 1992; Strauss, 1987), was iterative and the data analysis involved a number of readings of the data entries and progressive refining of emerging categories (These will be presented in the following section).

For the interpretation of the data, the study employed a sociocultural theory perspective that has recently had a significant impact on the analysis and interpretation of classroom experiences and the development of learning skills (Kramsch, 2002; Lantolf, 2000; Lantolf \& Thorne, 2006; Swain, Kinnear, \& Steinman, 2011). Sociocultural theory supports that human behavior is a result of the integration of socially and culturally constructed forms of mediation into human activity (Lantolf, 2000). In line with this way of thinking, journal entries were related to the sociocultural reality of the participants within the context under study. Therefore, the findings from the journals were interpreted and reflected upon through the realities of the participating teachers in the local educational system, society and culture these occurred.

The next section will present the results of the study where points will be made with regard to the function of CS illustrated by journal extracts. To safeguard the identities of participants, code names (initials) will appear next to the journal extracts.

\section{Presentation of Findings}

Reflecting on students' learning experience through their journal entries, several distinctive features and themes emerged. These were organized under three broad areas: 'cognitive support' (supporting and developing learning), 'affective support' (reassurance and psychological support) and 'systemic support' (administrative and information management associated with practical help and 
advice) informed mainly by the work of Tait (2000), Tait and Mills (2002) and Carnwell (2000).

\subsection{Cognitive Support}

CS were deemed important to students as the collaboration and exchange of ideas for academic support, development and consolidation of new input was essential, e.g.

"We worked in groups a lot today. We all expressed our views on the assessment of writing. I personally participated in the discussion, based on my experience, and had the chance to listen to other colleagues' views and compared them to mine" (E.K.)

CS contributed in supporting course outcomes. In the following extracts, the students highlight the contribution of CS in the writing of their course assignments, e.g.

"Today I found out that when preparing my assignment, I should be more practical and to the point: focus on one language area rather than trying to include all of them. This also needs to be in line with the books I teach because the texts I am going to select need to be taught in class in advance. At the end of the contact session, I realised that it is important to study the relevant literature" (A.P.)

"I feel that today's contact session gave me practical support for my studying and preparation of the next assignment. The fact that many terms were clarified made our reading of the material and preparation for the assignment easier. Actually we discussed the requirements of the 1st assignment in detail, we raised several issues on bibliography (quantity, style of references, etc) and the selection of the test for our assignment. I received loads of clarifications and ideas and the evaluation of specific examples of tests has contributed to the way I should think and work for the next assignment" (G.K.)

Students made other practical realizations with regard to writing such as: "be sure that everything is clear for me before starting writing" (E.R.), "check the rubrics of the assignment" (C.P.) and "use more references" (E.R.).

During the CS, the tutor presented and evaluated the strengths and weaknesses identified in the work of students. The feedback students received on their assignment during the CS contributed to clearer formulation of future action plans: 
"After my contact session my action point is: In the following weeks, I have to study the course material and take notes. I will look for more sources regarding my study and think about the requirements of the assignment. I will borrow relevant books and articles from the library; search the internet to find a published test to use in Assignment 2, study the test and its specifications; talk to my fellow students and exchange ideas in order to clarify things; talk to my tutor too and then start drafting my next assignment" (C.P.)

The use of high-quality materials in CS, a key component in fostering and maximising learner independence and self-sufficiency (Hurd, et al., 2001; Vanijdee, 2003), was another recurrent point in the journals. Indeed, mini-quizzes designed for each of the five contact sessions of the module were used to consolidate students' learning of the DL material through selfassessment activities. In the following extract, a student describes how the mini-quiz used in one of the CS helped in making her aware of key concepts of the module, e.g.

"In the mini quiz key concepts of the course were made clear. For example, the distinction between different views and generations of testing and the tasks they dictate. I enjoyed the authenticity and usefulness of the tasks we were engaged: the analysis, evaluation and re-design of a listening and speaking test" (E.D.)

In the following extract, another student describes how the mini-quiz used in a CS proved to be a helpful resource for her assignment preparation, e.g.

"Today I found out that the mini quizzes we work on in our contact sessions can be used as a helpful resource for the preparation of our assignments. The quizzes are really challenging and helpful. I can use them as a reference and guide for our assignments as well as a reflection of our teaching methods and techniques" (I.M.)

\subsection{Affective Support}

The opportunities offered by CS of growing relationships between members of the group was an important issue for the students overall. In the following extract, one of the participants stresses the importance of the personal contact with her fellow students and the faculty member during their CS, e.g. 
"Today I got to know my fellow students as well as the tutor. We come from so many different places around the country but we all have the same interests and practical problems to solve in our teaching contexts. This helped me a lot because I now know my colleagues a bit better and can contact those with similar teaching experiences" (A. P.)

The centrality of developing networks, an important part of the philosophy and methodology of the current program, and DL education in general, is highlighted in the following entries, e.g.:

"I found out the new contact details of our fellow learners from my tutor and now can communicate with my colleagues through e-mails" (I.M.)

"I didn't know that there was another student in our group who comes from Crete. I will get in touch with her from now on and talk about similar difficulties we will face and discuss questions that relate to our study through e-mails" (E.D.)

The use of mini-quizzes during CS had a positive impact on student psychology, e.g.

"Through the activities of the mini-quiz of today's contact session I confirmed my answers. I feel more confident about my reading of the relevant material. This made me feel more confident in studying the rest of the materials" (D.A.)

CS also offered continuous opportunities for collaboration and exchange of ideas among members of the group. This contributed towards psychological and motivational support and understanding which was vital to participants, e.g.:

"Today's contact session helped me a lot. I got the feeling that both the reading and the assignment are manageable" (V.B.)

CS helped in building and strengthening their self-confidence; especially in the case of struggling learners, this meant reassurance of their learning, too, e.g.:

"Even though I hadn't had the time to study the relevant chapters for today's meeting, I now have a clear idea of what and how to study the following chapters" (P.F.) 
"I am really happy I attended today's contact session. The reason was that students who hadn't studied the material yet like me were able to contribute and put things in practice" (E.M.)

The collaboration, mutual assistance and support in learning among participants in the face of practical problems (e.g. lack of equipment, bibliographical references etc) was encouraged during CS. In the following extract two students talk about the type of help they offered to the rest of the members of their group, e.g.:

"The two colleagues I worked with today admitted that they did not have the time to study the relevant chapters at home for various reasons. During our groupwork I helped my colleagues to carry out the tasks allocated to us: assess the reading and writing tasks included in an achievement test" (E.D.)

"During our contact session today I feel I helped my group a lot. I recommended a book to my partners who were not aware of this. I am going to email an important reference to my partners too (The Ministry Exam Specifications). I also brought extra materials with me today: The Teacher's handbook of YLE and KET. In my group we went through these documents and exchanged opinions on them. I am happy I managed to help my partners by providing copies of materials they didn't have" (T.D.)

\subsection{Systemic Support}

Students identified several IT strategies and sources they can use in their study during their CS, e.g.:

"During today's contact session I got help on how to download articles from our yahoo site, order books from the library and extra articles from Heal link to compile references for the teaching of the four skills. I will add this to what I have gathered from books. This will help me in the organization of the 1st assignment" (R. G.)

Time management is an important issue for the DL students who feel the need to organize and plan their work efficiently, e.g.: 
"From the discussion today I realized that I need to start planning my tasks earlier this time, drafting my assignments, downloading, etc." (D.A.)

"I have to organise my study time more effectively. During the contact session today I found out that I need to complete my studying and researching on time, so as to be able to start writing and editing my assignment earlier" (I.M.)

\subsection{Impact of Diary Writing}

The act of keeping a diary at the end of their contact sessions gave participants the opportunity to reflect on their personal development as teachers in the module and discuss the impact this is going to have on their teaching context. It is important to stress that the group of students under study were also teachersin-training in language testing and assessment. The reflective journals that teachers kept at the end of their CS offered them the opportunity to reflect on their awareness of language testing, such as the criteria used in the allocation of scores, use of rating scales, qualities of good tests, design and evaluation of test tasks, etc.

"In today's contact session I interacted with my fellow students and tutor. I became aware of my continuous development as a teacher" (E.Z.)

"During today's contact session I expressed my worries concerning scores of students in tests. I found out that we should also take into account students' behavior, effort and willingness to participate in the whole teaching-learning process apart from good/bad marks in a test" (A.P.)

"We worked on various types of rating scales used in published writing tests. I learned that to give a grade to a writing sample can be subjective even with the use of a rating scale. I feel that my awareness of marking writing was raised" (S.M.)

".... alternative assessment is a better way to motivate and assess students' needs (process rather than product)" (A.P.) 


\section{Discussion of Results}

This paper examined the need and usefulness of CS as part of a course delivery system in distance education for adults. The results of the study showed that the majority of students value the contribution of CS in supporting their studies. Students welcome CS and consider them a necessary and important process in DL. They perceive CS as an educational process where they are activated and learn how to operate autonomously. Students who have experienced conventional education system prior to their DL are in need of the support offered by CS

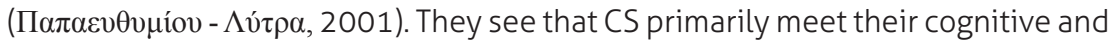
academic needs such as the exchange of ideas, experiences and understanding of knowledge included in the DL materials, guidance in their study and writing of their assignments. Students consider CS as a learning process during which they can become autonomous learners. Students find that CS mostly support their academic needs such as their desire to successfully complete their studies as stressed in other research, too (Fung \& Carr, 2000; Morgan \& Morris, 1994;

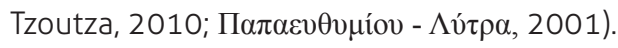

Unlike the findings of other research (Tzoutza, 2010), CS in the present study emphasized the development of a friendly learning environment. This was expressed in the practice of students to develop cooperation and establish channels of communication with the rest of the members of their group during and in between CS. It seems that students gradually acquire the view that, to succeed in their studies, it is necessary to adapt practices that accommodate the exchange and sharing of fellow students' concerns and views. It is also worth noting that the techniques used during the CS, such as group work, were appreciated by students as fostering appropriate learning and overcoming problems. In a similar study, B $\alpha \sigma \alpha ́ \lambda \alpha$ (2003) also found that students see that CS significantly contribute to the development of cooperation among them during the academic year as they meet their immediate educational needs.

Overall, the contribution of CS was positively experienced by the students participating in the study. The postgraduate students experienced CS in their various functions constructively, e.g. cognitive support, provision of information on the organization of their studies, encouragement for their studies by fostering a sound learning environment in providing quality learning that contributes in completing their studies. Data collected from participants' reflective journals suggested that CS reinforce distance education channels, e.g. strengthen interaction between students and tutors, reduce student isolation as CS can play a humanizing, motivating, and instructional role in distance education systems. In addition, during the CS, students became aware of their professional development. They were also found to possess the necessary capacity to self-direct their professional development (Richards \& Lockhart, 1994). The advantages of CS, as these are evidenced in the results of the study, 
give meaning and identity to distance education in order to achieve desirable educational goals. CS may ultimately be more important to the quality of the students' learning experience than singular focus on courseware as these facilitate the process by which learners establish an effective interface with their learning and professional development.

\section{Pedagogical and Research Recommendations}

Even though there have been experiments in various distance teaching institutions to diversify student support services with the objective of cutting down on CS in order to economise and take advantage of developments in Information and Communication Technologies (Bates, 2003; Burge \& Haughey, 2001; Escobar et al., 2003; Keegan, 2000; McVay Lynch, 2002; Perraton, 2000), face-to-face CS are indispensable. Without ignoring the practicalities involved in accommodating $\mathrm{CS}$ in $\mathrm{DL}$, the present study argues in favour of retaining CS in DL education. The often-isolated contexts of distance learners, the fact that many have limited access to learning resources and the learner training approach that CS offer, e.g. scaffolding opportunities for learners to manage their independence in optimal ways, should not be underestimated.

The present study has shown that CS can afford personal interaction among participants and contribute towards course completion. Therefore, CS need to be built into DL systems but these have to be well-organised and monitored closely. For example, participants have to make use of such sessions to make them cost effective and to achieve the desired results. In addition, during CS, tutors can choose from numerous educational techniques that engage students in active learning combining theory and practice and be suitable for adults. The activities in adult learning should be productive, as adults need to act and explore solutions (Rogers, 1999) and provide learners with guidance regarding how to develop a sense of responsibility for their professional development.

Further research into the role of CS should involve a larger sample that would give more generalisable results, e.g. involve students from other modules of the same DL programme or follow the same group over their years of DL study. It would also be interesting to complement the present research with observations of students' study at home to gain a clearer picture of DL students' individual study experiences. 


\section{References}

Agboola, B.A. 1993. Contact Session in Distance Education: An Asset As Well As a Burden. Indian Journal of Open Learning, 2(1), 77-22.

Anderson, T.D. and Garrison, D.R. 1998. Learning in a networked world: New roles and responsibilities. In C.C. Gibson (Ed.), Distance Learners in Higher Education: Institutional Responses for Quality Outcomes, 97-112. Madison, WI: Atwood Publishing.

Bailey, K.M. 1983. Competitiveness and Anxiety in Adult Second Language Learning: Looking at and through the Diary Studies. In H.W. Seliger and M.H. Long (Eds.), Classroom Oriented Research in Second Language Acquisition, 67103. Rowley, Mass.: Newbury House.

Bailey, K.M. and Ochsner, R. 1983. A methodological review of the diary studies: windmill tilting or social science? In K.M. Bailey, M.H. Long and S. Peck (Eds.), Second Language Acquisition Studies, 188-198. Rowley, M.A.: Newbury House Publishers, Inc.

Banerjee, J.V. 2004. Qualitative Analysis Methods (Section D). Reference Supplement to the Preliminary Pilot version of the Manual for Relating Language Examinations to the Common European Framework of Reference for Languages: learning, teaching, assessment. Strasbourg: Language Policy Division, Council of Europe.

Bates, A.W.T. 2003. Technology, Distributed Learning and Distance Education. London: Routledge Falmer.

Benson, P. 2001. Teaching and researching autonomy in language learning. London: Longman. 
Breen, M.P. and Littlejohn, A. (Eds.). 2000. The process syllabus: negotiation in the language classroom. Cambridge: Cambridge University Press.

Burge, E.J. and Haughey, M. (Eds.). 2001. Using Learning Technologies: International Perspectives on Practice. London and New York: Routledge Falmer Studies in Distance Education.

Carnwell, R. 2000. Approaches to Study and Their Impact on the Need for Support and Guidance in Distance Learning. Open Learning, 15(2), 123-140.

Charmaz, K. 2006. Constructing Grounded Theory: A Practical Guide Through Qualitative Analysis. Thousand Oaks, CA: Sage Publications.

Escobar, L., Rendon, E., Restrepo, J., Montoya, E., Zea, C. and Trefftz, H. 2003. Telepresence in Synchronous Distance Education Sessions., In Proceedings of the Second International Conference on Multimedia and ICTs in Education (M-ICTE 2003). Badajoz, Spain. http://arcadia.eafit.edu.co/Publications/mlcte2003Telepresence.pdf.

Fung, Y. and Carr, R. 2000. Face-to-Face Tutorials in a Distance Learning System: Meeting Student Needs. Open Learning, 15(1), 35-46.

Genesee, F., \& Upshur, J.A. 1996. Classroom-based evaluation in second language education. Cambridge: CUP.

Glaser, B. 1992. Basics of grounded theory analysis. Mill Valley, CA: Sociology Press.

Harichandan, D. 2005. Organization and management of learner support systems in dual mode universities of India. Paper presented at the ICDE International Conference, November 19-23, 2005, New Delhi, India.

Hettich, P. 1990. Journal Writing: Old Fare or Nouvelle Cuisine. Teaching Psychology, 17(1), 36-39.

Hiola, Y. and Moss, D. 1990. Student opinion of tutorial provision in the Universitas Terbuka of Indonesia. Open learning, 5(2), 34-38.

Holec, H. 1981. Autonomy and foreign language learning. Oxford: Pergamon. (First published [1979], Strasbourg: Council of Europe.)

Holmberg, B. (Ed.). 1982. Distance study at the postgraduate level. Edmonton: Athabasca University/ICCE. 
Hurd, S., Beaven, T. and Ortega, A. 2001. Developing autonomy in a distance language learning context: issues and dilemmas for course writers. System, 29(3), 341-355.

Jamtsho, S. 1999. Distance Education for In-service Teachers in Bhutan. Indian Journal of Open Learning, 8(1), 79-84.

Keegan, D. (Ed.). 2000. Foundations of distance education London and New York: Routledge Falmer Studies in Distance Education.

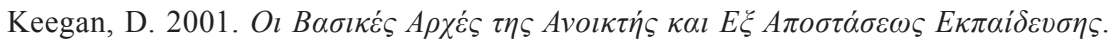

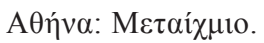

Kramsch, C.J. (Ed.). 2002. Language acquisition and language socialization: ecological perspectives. London, New York: Continuum.

Lantolf, J.P. (Ed.). 2000. Sociocultural Theory and Second Language Learning. Oxford: Oxford University Press.

Lantolf, J.P. and Thorne, S.L. 2006. Sociocultural Theory and the Genesis of Second Language Development. Oxford: Oxford University Press.

Laurillard, D. 2002. Rethinking university teaching. A conversational framework for the effective use of learning technologies (2 ed.). London: Routledge.

Little, D. 1991. Learner autonomy: Definitions, issues and problems. Dublin: Authentic.

Ljosa, E. 1975. The system of distance education. Papers presented to the 10th ICCE international conference, Brighton, Great Britain, 12-16 May, 1975. Hermounds, Malmo: Sweden. In M. Rashid (Ed.), Status of face-to-face instruction in distance education at AlOU. Turkish Online Journal of Distance Education, 10(2). http://tojde.anadolu.edu.tr/tojde34/articles/article_37. htm.

Matsumoto, K. 1987. Diary studies of second language acquisition: a critical overview. JALT Journal, 9(1), 17-34.

Mcasson, I.B. and Mcasson, N.L.G. 1997. Enhancing the effectiveness of Distance Education through guidance and counselling. ABSU Journal of Distance Education, 3(3), 88-93. 
McVay Lynch, M. 2002. The Online Educator: a Guide to Creating the Virtual Classroom. London and New York: RoutledgeFalmer

Morgan, C. and Morris, G. 1994. The student view of tutorial support: report of a survey of Open University Education students. Open Learning, 9, 22-33.

Nasseh, B. 1996. Study of computer-based distance education in higher education institutions in Indiana. Ball State University, Muncie. IN.

Palmer, C. and Palmer, G. 1994. Diary keeping and reflecting on practice. In A. Peck and D. Westgate (Eds.), Language Teaching in the mirror, 30-36. London: CILT (Centre for information on Language Teaching and Research).

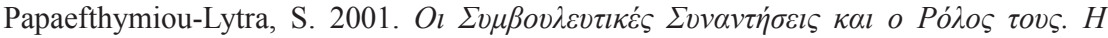

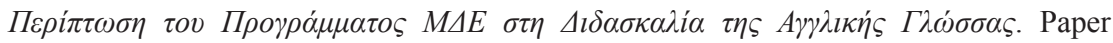

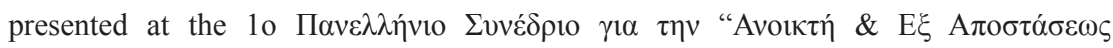

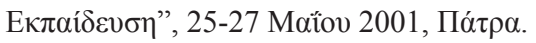

Paul, R. 1990. Towards a new measure of success: developing independent learners Open Learning, 5(1), 31-38.

Perraton, H. (Ed.). 2000. Open And Distance Learning In The Developing World. London and New York: Routledge Falmer Studies in Distance Education.

Rao, B.P.N., Soundaravalli, K. and Sarada, R. 1994. Approaches to preparing open university learners for practical contact sessions. In K.M. Manohar (Ed.), Distance education in India: studies in quality and quantitative aspects, 111-122. Warangal, India: Indian Distance Education Association, C/o School of Distance Learning and Continuing Education, Kakatiya University.

Rashid, M. 2009. Status of face-to-face instruction in distance education at AIOU Turkish Online Journal of Distance Education, 10 (2). http://tojde.anadolu.edu.tr/ tojde34/articles/article_37.htm.

Richards, J.C. and Lockhart, C. 1994. Reflective Teaching in Second Language Classrooms. New York: CUP.

Rogers, A. 1996. Teaching Adults (2 ed.). Buckingham: Open University Press.

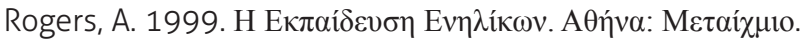

Rowntree, D. 1992. Exploring Open and Distance Learning. London: Kogan Page. 
Simpson, O. 2002. Supporting students in online, open and distance learning. UK: Kogan Page.

Stevenson, I. and Jenkins, I. 1994. Journal writing in the training of international teaching assistants. Journal of Second Language Writing, 3(2), 97-120.

Strauss, A. 1987. Qualitative analysis for social scientists. Cambridge: Cambridge University Press.

Sturman, P. 1996. Registration and placement: learner response. In K.M. Bailey and D. Nunan (Eds.), Voices From the Language Classroom, 338-355. Cambridge: CUP.

Swain, M., Kinnear, P. and Steinman, L. 2011. Sociocultural Theory in Second Language Education: An Introduction through Narratives. Bristol: Multilingual Matters.

Symon, G. 1998. Qualitative research diaries. In G. Symon and C. Cassell (Eds.), Qualitative methods and analysis in organizational research: a practical guide, 94117. London: Sage Publications Inc.

Tait, A. 2000. Planning Student Support for Open and Distance Learning. Open Learning, 15(3), 287-299.

Tait, A. and Mills, R. 2002. Rethinking Learner Support in Distance Education. London: Routledge.

Tzoutza, S. 2010. Face-to-face tutorials: The views of postgraduate students and their tutors at the Hellenic Open University. The case of postgraduate course on "Open and Distance Education" at the Hellenic Open University. Open Education - The Journal for Open and Distance Education and Educational Technology, 6/1 \& 2), 46-65.

Ushadevi, M.D. 1994. Are Contact Sessions Necessary in Distance Education? A Feedback to IGNOU. Indian Journal of Open Learning, 3(1), 16-21.

Vanijdee, A. 2003. Thai distance English learners and learner autonomy Open Learning 18(1), 75-84.

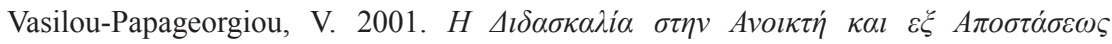

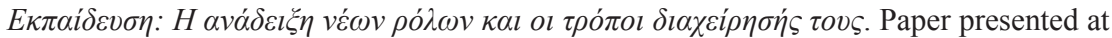

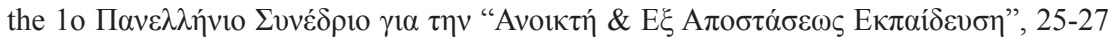

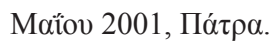


White, C.J. 1995. Autonomy and strategy use in distance foreign language learning: research findings. System 23(2), 207-221.

White, C.J. 1997. Eliciting and analysing expectations of novice distance learners. Journal of Distance Learning, 3(1), 3-11.

White, C.J. 2003. Language learning in distance education. Cambridge: Cambridge University Press.

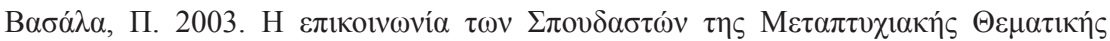

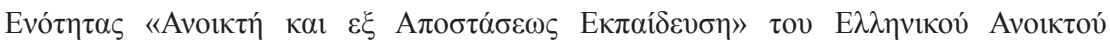

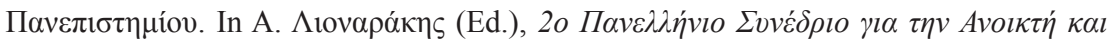

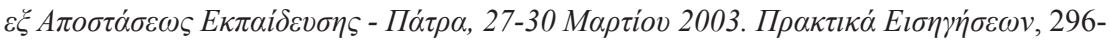

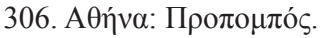

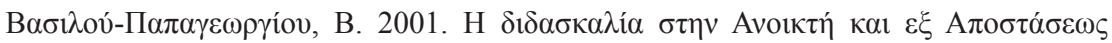

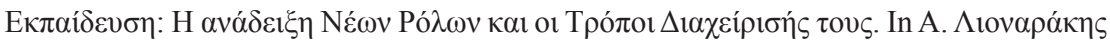

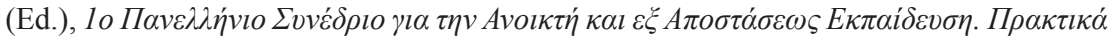

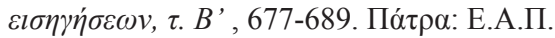

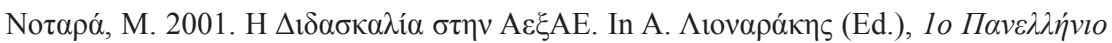

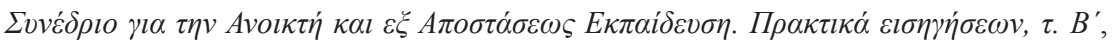

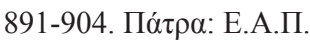

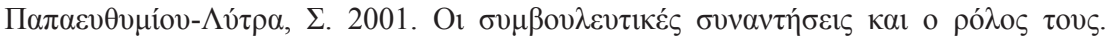

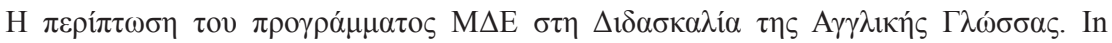

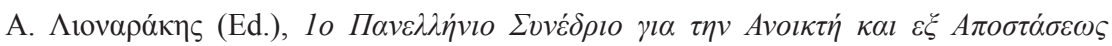

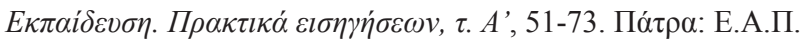




\section{Appendix}

My Journal Entry

(Contact Session No: ...........)

a. What I really liked about today's sessions was

b. I was less interested in

c. The 3 most important things I want to remember about today are:

1.

2.

3.

d. My contributions during today's session were:

e. My action points in the future are:

My name is: 
Major Trends in Theoretical and Applied Linguistics 